\title{
'Fengshan 036', a White Bitter Gourd Cultivar
}

\section{Tsung-Dao Liou ${ }^{1}$, Kan-Shu Chen ${ }^{2}$, Shough-Peng Lee ${ }^{3}$, and Jaw-Neng Lin $^{4}$}

Fengshan Tropical Horticultural Experiment Station, Taiwan Agricultural Research Institute, Council of Agriculture, Fengshan, Kaohsiung, Taiwan 830

Shing-Jy Tsao ${ }^{5}$

Department of Horticulture, National Taiwan University, Taipei, Taiwan 106

\section{Yau-Wen Yang 6}

Institute of Botany, Academia Sinica, Nankang, Taipei, Taiwan 115

More than 80 species occur in genus Momordica, which is a native of the old world tropics, mainly Africa (Mini Raj et al., 1993). Bitter gourd (Momordica charantia Linn.) is one of these species and is widely cultivated in China, Malaysia, India, and tropical Africa (Mini Raj et al., 1993; Singh, 1990). This crop requires an extensive period of warm temperatures for its growth and development, and its fruits can be used in various culinary dishes (Mini Raj et al., 1993; Robinson and DeckerWalters, 1997). In addition, it is used as common remedies for cold, fever, rheumatism, and arthritis in the Caribbean (Schultes, 1990) and contains possible anti-tumor ingredients (Xue et al., 1998). In southern Taiwan, three major cultivars, 'Pingtong Black Seed', 'Moonshine', and 'Highmoon', are used for white fruit production by wrapping the fruit $2-3 \mathrm{~d}$ after pollination with a paper or plastic bag. The fruits of these three cultivars are green and in long spindle shape. 'Moonshine' and 'Highmoon' are $\mathrm{F}_{1}$ hybrids, while 'Pingtong Black Seed' is an open-pollinated cultivar. 'Pingtong Black Seed' is more heat-tolerant and harder to crack than the other two cultivars during the hot and humid growing season. 'Pingtong Black Seed' comprises $70 \%$ of production, while 'Moonshine' comprises 20\% and 'Highmoon' comprises $<10 \%$ of production in southern Taiwan. Since extensive labor is required for bagging fruit with a plastic or paper bag and increases the cost of production, breeding a white cultivar of bitter gourd with similar quality to 'Pingtong Black Seed' will

Received for publication 30 Oct. 2001. Accepted for publication 28 Apr. 2002. We thank Mr. Chou Hung, Yale Univ., and Drs. M.C. Chung, H.-M. Hsieh and Y.-M. Ju, Institute of Botany, for their critical reading of this manuscript. This work was partly supported by Council of Agriculture, Taiwan.

${ }^{1}$ Senior Horticulturist

${ }^{2}$ Associate Horticulturist.

${ }^{3}$ Assistant Horticulturist.

${ }^{4}$ Research Assistant.

${ }^{5}$ Associate Professor.

${ }^{6}$ Associate Research Fellow, to whom reprint requests should be addressed;

e-mail: yauwen@sinica.edu.tw pollination. Scale bars represent $5 \mathrm{~cm}$. cultivar with light green or green pearl-like tubercles on its surface and has dark brown seeds (Fig. 1A). 'Fengshan 036' has a white fruit, with a fruit shape similar to 'Pingtong Black Seed' and has light brown seeds (Fig. 1A). Although white fruit color was thought to be controlled by a recessive gene (Mini Raj et al., 1993), at least $5 \%$ of the progeny revert back to green fruits after the first selfing. In addition, some of the progeny continue to exhibit green spots on their epicarp. To preserve its growth vigor, this mutant was sibmated for two generations after being selfed for four generations. Currently, nearly all the progeny produce white fruits.

\section{Description}

Similar to 'Pingtong Black Seed', be more economic for production of this crop. In order to reach the goal, a white fruit cultivar, 'Fengshan 036', was generated from the progeny of 'Pingtong Black Seed'. 'Fengshan 036' has a similar fruit shape to its parental line but produces lower yields. The origin and the characteristics of 'Fengshan 036' are herein described.

\section{Origin}

'Fengshan 036' was derived in 1995 from a white epicarp mutant of 'Pingtong Black Seed', which was found in the field at the Fengshan Tropical Station, Kaoshiung, located in southern Taiwan (Fig. 1A-B). 'Pingtong Black Seed' is an open-pollinated
'Fengshan 036' has a long spindle fruit shape and pearl-like tubercles with the fruit length ranging from 23 to $28 \mathrm{~cm}$ and the fruit width ranging from 7.2 to $9.0 \mathrm{~cm}$. It has a smoother fruit shoulder than 'Pingtong Black Seed'. The thickness of the mesocarp ranges from 1.2 to $1.7 \mathrm{~cm}$. In southern Taiwan with an average daily temperature of $28^{\circ} \mathrm{C}$ in the fall, 'Fengshan 036' can bear fruits earlier than 'Pingtong Black Seed', 'Moonshine', and 'Highmoon'. In Fall 2000 at Fenshan Experiment Station, soybean compost, chicken manure, and $15 \mathrm{~N}-$ $6.5 \mathrm{P}-12.4 \mathrm{~K}-2.4 \mathrm{Mg}$ fertilizers were applied to soil at 2000-3000 kg, 12,000-20,000 kg, and $800 \mathrm{~kg} \cdot \mathrm{ha}^{-1}$, respectively. Plants were sidedressed every 2 weeks after initial plant-
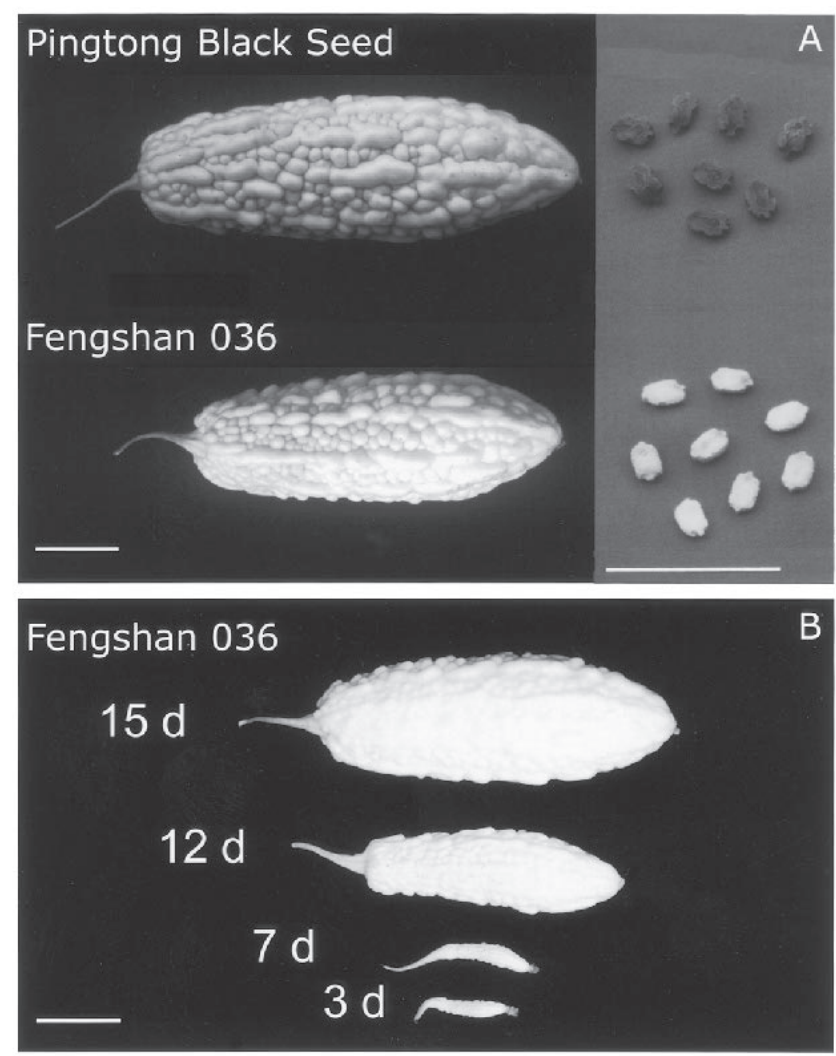

Fig. 1. Fruit of 'Fengshan 036' and its parental line, 'Pingtong Black Seed'. (A) dark brown seeds ('Pingtong Black Seed') vs. light brown seeds ('Fengshan 036') and (B) different developmental stages of fruits after 
ing date with $15 \mathrm{~N}-6.5 \mathrm{P}-12.4 \mathrm{~K}$ fertilizer $(400$ $\left.\mathrm{kg} \cdot \mathrm{ha}^{-1}\right)$. Three-week-old seedlings were transplanted in 4-m-wide, single-row beds. The spacing between beds was $50 \mathrm{~cm}$ and that between plants was $1.6 \mathrm{~m}$. Aluminum arches with a radius of $1.8 \mathrm{~m}$ were used to support the plants in a net greenhouse to prevent melon flies and heavy rain from entering. First flowers appeared $53 \mathrm{~d}$ after transplanting for 'Fengshan 036', $60 \mathrm{~d}$ for 'Pingtong Black Seed', and $65 \mathrm{~d}$ for 'Moonshine'. The fruits were harvested 12-15d after pollination. Each plant yielded $\approx 30$ fruits for 'Fengshan 036', 40 fruits for 'Pingtong Black Seed', and 45 fruits for 'Moonshine' during the $60 \mathrm{~d}$ after first fruit set. Fruit averaged $510 \pm 30 \mathrm{~g}$ for 'Fengshan 036', $450 \pm 20 \mathrm{~g}$ for 'Pingtong Black Seed', and $395 \pm 14 \mathrm{~g}$ for 'Moonshine' for the second fruit harvested for each plant. Field yield tests between 'Fengshan 036' and other commercial cultivars were also conducted from 2000 to 2001. In the field of Taitong, southeast of Taiwan, the yield of 'Fengshan 036' was estimated $23.3 \pm 2.3 \mathrm{t} \cdot \mathrm{ha}^{-1}$ and the yield of 'Moonshine' was $20.6 \pm 1.2 \mathrm{t} \cdot \mathrm{ha}^{-1}$ with seedling density of 1600 plants per hectare. In the field of Pingtong, the southernmost of Taiwan, the yield of 'Fengshan 036' was $16.8 \pm 1.2 \mathrm{t} \cdot \mathrm{ha}^{-1}$ and the yield of a local strain of 'Pingtong Black Seed' was $20.6 \pm 1.2 \mathrm{t} \cdot \mathrm{ha}^{-1}$ with seedling density of 800 plants per hectare.

\section{Availability}

Seed samples can be obtained from YauWen Yang, Institute of Botany, Academia Sinica, Nankang, Taipei, Taiwan 11529.

\section{Literature Cited}

Mini Raj, N., K.P. Prasanna, and K.V. Peter. 1993. Bitter gourd Momordica spp., p. 239-246. In: G. Kalloo and B.O. Bergh (eds.). Genetic improvement of vegetable crops. Pergamon Press, Oxford, U.K.

Robinson, R.W. and D.S. Decker-Walters. 1997. Cucurbits. CAB Intl., Oxon, U.K.

Schultes, R.E. 1990. Biodynamic cucurbits in the new world tropics, p. 307-317. In: D.M. Bates, R.W. Robinson, and C. Jeffrey (eds.). Biology and utilization of the cucurbitaceae. Cornell Univ. Press, New York.

Singh, A.K. 1990. Cytogenetics and Evolution in the cucurbitaceae, p. 10-28. In: D.M. Bates, R.W. Robinson, and C. Jeffrey (eds.). Biology and utilization of the cucurbitaceae. Cornell Univ. Press, New York.

Xue, Y., S.H. Song, and H. Chen. 1998. Possible antitumor promoting properties of bitter gourd and some Chinese vegetables. Acta Hort. 467:55-62. 